\title{
Tectonic evolution of Les Saintes archipelago (Guadeloupe, French West Indies): relation with the Lesser Antilles arc system
}

VERATI Chrystèle1, Yves MAZABRAUD2, Jean-Marc LARDEAUX1, Michel CORSINI1, Dorian SCHNEIDER1, Emile VOITUS2 and Fabienne ZAMI3

Mots-clés. - Tectonique cassante, champ de déformation finie, Paléo-système géothermal, Réactivation tectonique, Archipel des Saintes, Petites Antilles, Implications géodynamiques

Résumé. - Cette étude propose la première carte structurale du réseau de failles de l'archipel des Saintes (Guadeloupe, Petites Antilles). Le champ de déformation finie obtenu montre quatre familles de systèmes de failles caractérisées par les directions statistiques suivantes: une famille N000-N020, une N050-N070, une N090-N110, et une N130-N140.

Notre étude structurale à terre montre que ce réseau de failles est bien plus complexe que celui déterminé par les études géophysiques en mer autour de l'archipel des Saintes, sachant qu'elles ne mettent en évidence qu'une seule famille de failles de direction N120-N150. En combinant les âges K-Ar disponibles sur les roches volcaniques des Saintes avec la chronologie relative observée sur le terrain entre les différentes familles de failles, nous avons déterminé l'histoire de la déformation des îles des Saintes depuis $3 \mathrm{Ma}$. Les quatre systèmes de failles mis en évidence étaient déjà actifs depuis le Pliocène et sont cohérents avec la tectonique actuelle en extension à l'échelle de l'archipel de Guadeloupe. Cette tectonique

actuelle, ainsi que celle qui perdure depuis $3 \mathrm{Ma}$ aux Saintes, est aussi compatible avec la réactivation de structures tectoniques héritées présentes à l'échelle de l'arc actif. Nous interprétons l'évolution tectonique aux Saintes comme le résultat de l'interaction de la subduction de rides asismiques (rides de Barracuda et Tiburon) avec la convergence oblique dans l'arc. De plus, nous avons identifié sur le terrain un paléo-champ géothermal exhumé sur l'île de

Terre-de-Haut, qui est un bon analogue du système géothermique actuel de Bouillante. Sa durée de fonctionnement au Pliocène est estimée à 400 k.y.

\section{INTRODUCTION}

The Lesser Antilles arc is located at the convergent boundary between the Caribbean and the North-American plates. This convergence is accommodated by subduction of Atlantic lithosphere under the arc (fig. 1) at rates of about $2 \mathrm{~cm} / \mathrm{yr}$ [DeMets et al., 2000; Lopez et al., 2006]. Within the Guadeloupe archipelago, the Lesser Antilles arc is divided into two subparallel ridges (fig. 1) [Westercamp, 1979].

The eastern one is an ancient arc composed of islands topped by uppermost Miocene and Plio-Quaternary carbonate platforms situated in a forearc setting (Marie-Galante, Grande-Terre of Guadeloupe) [Andreieff et al., 1989; Bouysse et al., 1990; Cornée et al., 2012; Münch et al., 2013, 2014]. These carbonate platforms were deposited upon an Eocene to late Oligocene volcanic arc overlying Mesozoic basement [Bouysse et al., 1983, 1990; Bouysse and Westercamp, 1990]. La Desirade island corresponds to the unique exhumed and preserved portion of this Jurassic Caribbean basement in the entire Lesser Antilles arc [Bouysse et al., 1983; Cordey and Cornée, 2009; Mattinson et al., 2008; Corsini et al., 2011; Lardeaux et al., 2013]. The western arc is composed of a chain of volcanic islands (Les Saintes archipelago, Basse-Terre of Guadeloupe, Montserrat) and corresponds to the recent active arc at least for ca. 5 Ma ago [Bouysse, 1979, 1988; Jacques et al., 1984; Bouysse and Westercamp, 1990].

Last ten years, field geological studies [Feuillet et al., 2002; Thinon et al., 2010; Mathieu et al., 2011; Corsini et al., 2011; Lardeaux et al., 2013] as well as marine geophysical surveys [Feuillet et al., 2010, 2011; Laigle et al., 2013; Münch et al., 2013; Leclerc et al., 2014] bring out significant onshore and offshore fault networks in the Guadeloupe archipelago. Some of these faults are seismically active, and all the faults likely control (1) the volcanic activity from Montserrat to Martinique island, and (2) the superficial earthquakes encountered in the overriding plate of the subduction system. Moreover, it has been proved in the Basse-Terre that this fault network enables the hydrothermal fluid circulation and thus is responsible for the geothermal 
resources exploited in the Bouillante bay [Bouchot et al., 2010; Calcagno et al., 2012; Verati et al., 2014]. The archipelago of Les Saintes, located southeast of Basse-Terre of Guadeloupe (fig. 1), is surrounded by a submarine carbonate plateau (fig. 2), and consists of typical calc-alkaline volcanic rocks from insular arcs, with ages ranging from $4.7 \pm 0.35 \mathrm{Ma}$ to $0.64 \pm 0.10 \mathrm{Ma}$ [Jacques et al., 1984 ;

Jacques and Maury, 1988]. However, the latest geochronological study from Zami et al. [2014], demonstrates that some previous K-Ar ages [Jacques and Maury, 1988] were not accurate especially with respect to the technique and minerals used for the analyses. The ancient K-Ar data were obtained on whole rock, whereas the new ones were made on groundmass using the Cassignol-Gillot technique [Zami et al., 2014]. Furthermore, the previous K-Ar ages from Jacques et al. [1984] were often discordant with the new K-Ar ages from Zami et al. [2014] obtained for the same formation. Therefore, we consider only the new $\mathrm{K}$-Ar ages from Zami et al. [2014] suggesting that the volcanism in Les Saintes archipelago was not continuous as previously inferred. These authors defined precisely three volcanic phases in Terre-de-Haut island: Phase I at $2.98 \pm 0.04 \mathrm{Ma}$, Phase II at $2.40 \pm 0.04 \mathrm{Ma}$ and Phase III from $2.08 \pm 0.03$ to $2.00 \pm 0.03 \mathrm{Ma}$, respectively, and a single one in TerredeBas island $(0.889 \pm 0.032 \mathrm{Ma}$ to $0.916 \pm 0.014 \mathrm{Ma})$

(fig. 1B).

The volcanic activity in Les Saintes archipelago began thus at ca. $3 \mathrm{Ma}$ in Terre-de-Haut island and was simultaneous with the northern Basse-Terre volcanism [Samper $e t$ al., 2007]. It ended at ca. $0.89 \mathrm{Ma}$ with the construction of Terre-de-Bas island which was coeval with the volcanic activity of the Axial Chain in Basse-Terre [Samper et al., 2007]. Volcanic formations correspond mainly to (1) dacitic to andesitic domes (Le Chameau in Terre-de-Haut, and Morne Abymes in Terre-de-Bas), (2) few basaltic lava flows, and (3) many debris flows caused by lahars and/or restricted flank-collapses (fig. 1B, 2B, 2C).

Although some onshore faults were already identified, the tectonic evolution of Les Saintes is poorly known. In this paper, we first document the finite brittle strain pattern by the production of a detailed map of the faults network in the Saintes archipelago, second we discuss the relative chronology between the different generations of structures and kinematics indicators in order to establish the history of deformation in this archipelago and third we interpret the recent finite strain pattern with respect to the dynamics of the Lesser Antilles subduction zone at the vicinity of the Guadeloupe archipelago. This work contributes also to a better understanding of the origin of the geological hazards related to active deformation as well as the controlling factors of geothermal resources in Guadeloupe.

\section{STRUCTURAL ANALYSIS AND FINITE DEFORMATION PATTERN OF LES SAINTES ARCHIPELAGO}

The structural analysis of the different islands constituting Les Saintes archipelago was performed, combining the observations and measurements in the field, the analysis of aerial photographs and topographic maps. The measurable onshore finite deformation pattern displays four families of 
faults systems characterized by their statistical structural directions

(fig. 2, 3 and 4): N000-N020, N050-N070,

N090-N110 and N130-N140 trending fault systems.

The fault zones present a large variety of dips, but are generally deeply dipping. Indeed, at the scale of the studied zone faults dip is superior most of the time to 50 degrees. In the field, the faults are characterized by damaged zone

(from a few centimeter to a meter thickness) with the development of cataclasites and fault breccias (see for example the figure 3B). Despite an unfavorable lithology, fault surfaces with scarce slickensides and striations can be observed.

However, kinematic indicators such as volcanic lithology shifts or fractured and shifted fragments of volcanic breccias (fig. 3) are well expressed in the field. Along with our morphostructural observations, these indicators demonstrate that the four faults systems display normal-slip movements, and for three of them strike-slip ones (senestral or dextral). Indeed, the N090-N110 trending fault system is the only one without any evidence for strike-slip movement. Contrasting with other fault families, the N130-N140 trending family displays a rather moderate dip from 30 to 50 toward the SW or the NE and corresponds to normal faults with a sinistral strike-slip component. On the other hand, for the N000-N020 and N050-N070 systems, kinematic indicators show contradictory shear senses (i.e. dextral and sinistral strike-slips for the two systems) suggesting

that these faults were active and reactivated at different stages during the tectonic evolution of Les Saintes archipelago.

Our results clearly highlight an onshore finite strain pattern much more complex than the one depicted by the offshore geophysical investigations performed on Les

Saintes plateau [Feuillet et al., 2011; Leclerc et al., 2014; De Min, 2014], which highlight mainly a dominant N120-N150 fault system.

In the eighties, Jacques et al. [1984] and Jacques and Maury [1988], identified a highly hydrothermalized zone in the central part of Terre-de-Haut island (fig. 2B), within which andesitic rocks are deeply altered giving rise to a typical mineral assemblages of quartz, pyrite, chalcedony, gypsum and clays minerals. In thin sections, the development of the hydrothermal mineralogy is sequential. We observed a first high-temperature association composed of (1) chlorite and epidote aggregates developed as pseudomorphs at the expense of primary magmatic plagioclases and clinopyroxenes or (2) chlorite, serpentine and oxydes aggregates developed at the expense of primary magmatic orthopyroxenes. The pseudomorphosed minerals are cut by networks of millimeter scale veinlets filled either by quartz, chalcedony and pyrite or chlorite, smectite and goethite aggregates.

In some cases, the veinlets connect vesicles filled with chalcedony and isotropic zeolites. Finally, an advanced argilic overprint (alteration) leads the development of kaolinite, illite, montmorillonite and smectite. In the most altered samples, gypsum and jasper can be observed. The relictual high-temperature hydrothermal paragenesis and its retrogression during cooling are characteristic of high temperature hydrothermal alteration in epithermal settings [Patrier et al., 2013]. Thus, the hydrothermalized zone in the central part of Terre-de-Haut island represents a geothermal paleo-system. The structural analysis of Terre-de- Haut clearly shows that the development of this hydrothermalized 
area is controlled by the intersection of the N090-N110 and the N130-N140 normal faults (fig. 2). The intersection of these two fault families is responsible for the collapse of the central part of the Terre-de-Haut island contemporaneous with the development of a geothermal system similar, if we consider its structural and epithermal settings, to the present-day active Bouillante geothermal system [Bouchot et al., 2010; Calcagno et al., 2012; Patrier et al., 2013; Verati et al., 2014]. Therefore, the exhumed TerredeHaut geothermal paleo-system offers a unique opportunity to observe an analogue of the deep parts of active high-temperature geothermal systems.

\section{HISTORY OF DEFORMATION}

Cartographically, crosscutting relationship of the faulting structures allows us to propose a relative chronology for the development of the four recognized fault families. From the oldest to the most recent ones we find: (1) N050-N070, (2) N130-N140, (3) N090-N110, and (4) N000-N020 oriented faults. Some typical crossed intersections are shown in figure 3. All these fault systems affect the volcanic formations emplaced between 3 and 2 Ma in Ilet Cabrits, Grand Ilet and Terre-de-Haut islands (volcanic phases I to III, see figures 1 and 4). The most recent volcanic plugs (figs 1 and 2) with an age of $1.94 \pm 0.10 \mathrm{Ma}$ [Jacques et al., 1984; Jacques and Maury, 1988] in Terre-de-Haut island seems not to be affected by these faults. However, Le Chameau volcanic edifice, dated at $2.00 \pm 0.03 \mathrm{Ma}$ [Zami et al., 2014], is clearly affected by the various faults suggesting that the four fault systems were active from 3 to $2 \mathrm{Ma}$.

Nevertheless, the hydrothermal activity affects only the volcanic rocks of the second volcanic phase, suggesting that the geothermal paleosystem in Les Saintes archipelago was only active during this volcanic phase.

In the Terre-de-Bas island (fig. 2C and fig. 4), the four fault families affect the less than $1 \mathrm{Ma}$ old volcanic formation (phase IV). Thus, at the scale of Les Saintes archipelago, the four generations of identified normal faults worked since $3 \mathrm{Ma}$ and were still active $0.889 \pm 0.032 \mathrm{Ma}$ ago. Interestingly, the $2004 \mathrm{Mw} 6.3$ Les Saintes earthquake [Beauducel et al., 2005] shows that the inherited faults networks are likely to be reactivated during the present-day plate convergence. This intraplate earthquake, which occurred offshore at 14 kilometers depth along the Roseau fault (fig. 2), with a long aftershock sequence [Beauducel et al., 2005; Bazin et al., 2010], was indeed correlated to a pure normal faulting with NW-SE trending nodal planes which are compatible with the identified onshore N130-N140 faults.

\section{DISCUSSION}

\section{Age and time-scale of the paleo-geothermal system} activity

The oldest volcanic rocks affected by the hydrothermal activity are dated at $2.40 \pm 0.04 \mathrm{Ma}$ [Zami et al., 2014], while none of the volcanic plugs, dated at ca. 2.0 Ma (i.e. $1.94 \pm$ 0.10 Ma by Jacques et al. [1984]), are hydrothermalized even when they are located within the main hydrothermal zone (fig. 1 and 2). Therefore age of hydrothermalism is well constrained within this time span. This age contrasts 
significantly with the age of $250 \mathrm{ka}+/-50 \mathrm{ka}$ recently obtained on the Bouillante geothermal field [Verati et al.,

2014] and demonstrates that geothermal systems are episodically

active during volcanic arc building within

overriding plate of subduction zones.

The duration of hydrothermal activity (i.e. timescales

for efficient fluids and heat transfers) in high-enthalpy geothermal

systems is still a poorly constrained factor, mainly

because geochronological studies on active geothermal

fields are rare [see review in Verati et al., 2014]. Our results

offer an interesting opportunity to address this question. Indeed,

following the previous discussion, a maximal

timescale of about 400 ky must be envisaged for Les Saintes paleo-geothermal system activity. This result is in

agreement with first the timescale $(\mathrm{n} \sim 100 \mathrm{ky})$ proposed for

geothermal provinces, such as the Taupo volcanic zone

where hydrothermal activity is very intense [Rowland and

Sibson, 2004] and second, the timing of the geothermal activity

recently obtained on the Bouillante geothermal field

[Verati et al., 2014]. The studied fossil geothermal system

is therefore an eroded analogue of the active Bouillante one

whatever the considered controlling factors are (i) tectonic

setting, (ii) hydrothermal mineralogy and (iii) duration of

activity.

\section{Les Saintes finite strain pattern in the tectonic}

framework of the Guadeloupe archipelago

The brittle finite strain pattern depicted in Les Saintes islands

is clearly compatible with the whole tectonic picture

now proposed for the whole Guadeloupe archipelago (fig. 1).

The four generations of faults identified in Les Saintes islands

are indeed described at the scale of the whole archipelago

[Feuillet et al., 2001, 2002; Thinon et al., 2010;

Mathieu et al., 2011; Calcagno et al., 2012; De Min, 2014;

De Min et al., 2015]. The N050-N070 fault system corresponds

to the valley of La Desirade and to the northern vast

scarps bordering this island. The N090-N110 fault system

corresponds to the Marie-Galante graben, and the N130-N140

system is compatible to the normal and strike-slip fault system

of Montserrat-Bouillante (fig. 1). The N000-N020 fault

system is up to now less reported in the Guadeloupe archipelago,

although some N005-N160 trending fault systems

were described:

- in the Basse-Terre, Bouillante bay [Calcagno et al.,

2012], lava dome of La Soufrière volcano (the Ty fault,

Feuillet et al., 2002; Nicollin et al., 2006], and the Northern

Chain [Mathieu et al., 2011, 2013];

- in the Marie-Galante basin [De Min, 2014]

- in the Karukera spur (fig. 1A) [De Min et al., 2015].

According to the structural analysis and the relative

chronology of fault generations, our observations agree

with recent results obtained in La Desirade island, where

outcrop the oldest known rocks of the Caribbean plate

[Corsini et al., 2011; Lardeaux et al., 2013]. In La Desirade island, it has been proposed that the N050-N070 and

N130-N150 trending system are early structures related to

the Cretaceous tectonic evolution of the Caribbean plate.

Furthermore, structural relationships show that the

N130-N150 fault system crosscuts the N050-N070 trending

structures. In La Desirade, as in Les Saintes islands, these

two systems are crosscut by the N090-N110 trending structures.

In La Desirade island, relationships between tectonic

and sedimentology demonstrated that this latter fault generation 
was active since the Pliocene [Lardeaux et al., 2013;

Münch et al., 2014]. Moreover, in the Marie Galante basin,

recent tectono-stratigraphic investigations have demonstrated

first that both N120-N140 and the N160-N000

trending systems were active during Oligo-Miocene times

and second that the N090-N110 fault system was active

since Lower Pliocene [De Min, 2014]. In Les Saintes archipelago,

the relationships between finite strain pattern and

volcanic geochronology indicate that these structures were

also active $3 \mathrm{Ma}$ ago.

\section{Consequences for dynamics of Lesser Antilles subduction at the latitude of the Guadeloupe archipelago}

The depicted deformation history in Les Saintes islands confirms the existence of four fault systems active since the Pliocene and therefore demonstrates that the present-day extensional tectonics in the Guadeloupe archipelago is governed by the reactivation of inherited structures. As proposed by Feuillet et al. [2001, 2002], arc-parallel extension, demonstrated by the activation (and/or reactivation) of N090-N110 normal faults associated with N120-N140 strike-slip faults, can be explained by the obliquity of the convergence between the North-American plate and the Carribean plate. However, arc-perpendicular extension is also efficient, as underlined by the development of N170-N020 faults, sometimes conjugated with N120-N140 normal faults. Together with the reactivation of the N050-N070 normal faults system, these structural data are compatible with a multi-directional extension within the upper plate of the subduction system. As proposed in the nineties in a seminal paper by Bouysse and Westercamp [1990], such a tectonic regime can be the result of the subduction of non-buoyant ridges. Indeed, at the latitude of the Guadeloupe archipelago, two WNW-ESE trending aseismic ridges (Barracuda and Tiburon ridges), located upon the subducted Atlantic oceanic crust, have been imaged through various geophysical investigations [Stein et al., 1982; Mauffret et al., 1984; Olivet et al., 1984; Westbrook et al., 1984;

Bouysse and Westercamp, 1988, 1990; Sandwell and Smith, 2009; Laigle et al., 2013]. The subduction of such roughness can increase significantly the mechanical coupling at the subduction interface and this interaction is susceptible to induce both the tectonic reactivation of pre-existing fault networks and the development of arc-perpendicular extension. Consequently, we propose to interpret the tectonic evolution of Les Saintes islands, in the framework of the Guadeloupe archipelago, as the result of interplay between subduction of aseismic ridges and oblique convergence.

\section{CONCLUSIONS}

1 - The brittle finite strain pattern depicted in Les Saintes islands results from the development of four fault systems already active since the Pliocene. From the oldest to the most recent ones we recognized N050-N070, N130N140,

N090-N110, and N000-N020 oriented fault systems. This finite strain pattern is compatible with the whole tectonic evolution proposed for the Guadeloupe archipelago and demonstrates that the present-day extensional tectonics in 
this archipelago is governed by the reactivation of inherited structures.

2 - The tectonic evolution of Les Saintes islands confirms that both arc-parallel and arc-perpendicular extensions are developed in the Lesser Antilles volcanic arc. In the framework of the Guadeloupe archipelago, we interpret this recent to present-day tectonic pattern as the interplay between oblique convergence and aseismic ridges subduction. 3 - The hydrothermalized zone recognized in the central part of Terre-de-Haut island represents a geothermal paleosystem. Its activity, controlled between 2.4 and $2.0 \mathrm{Ma}$ by the intersection of the N090-N110 and the N130-N140 normal faults, lead the development of high-temperature hydrothermal paragenesis typical for epithermal settings. This paleo-system offers a unique opportunity to observe an analogue of the deep parts of the active Bouillante high-temperature geothermal system.

\section{$\mathrm{REF}$}

AndReiefF P., Bouysse P. \& Westercamp D. (1989). - Géologie de l'arc insulaire des Petites Antilles et évolution géodynamique de l'Est-Caraïbe. - Documents du Bureau de Recherches Géologiques et Minières, 171

Bazin S., Feuillet N., Duclos C., Crawford W., Nercessian A., BengoubouValerius M., Beauducel F. \& Singh S.C. (2010). -

The 2004-2005 Les Saintes (French West Indies) seismic aftershock sequence observed with ocean bottom seismometers. -

Tectonophysics, 489, 91-103.

Beauducel F., Antenor-Habazac C., Bazin S., De Chabalier J.-B., Nercessian

A., Feulllet N., Jacques E., Bertil D., Boudon G.,

Lefriant A., Tapponnier P., Hirn A., Lepine J.-C., Bernard P.,

Komorovsкi J.-C. \& King G.C.P. (2005). - The Mw 6.3 earthquake

of Les Saintes (Guadeloupe) on November 21, 2004. -

IAVCEI European Seismological Commission Annual Workshop,

Saint-Claude Guadeloupe, Sep. 2005.

Bouchot V., Sanjuan B., Traineau H., Gulllou-Frottier L., Thinon I.,

Baltassat J.M., Fabriol H., Bourgeois B. \& Lasne E. (2010). -

Assessment of the Bouillante geothermal field (Guadeloupe,

French West Indies): toward a conceptual model of the high temperature

geothermal system. In: Proceedings of the World Geothermal

Congress 2010, Bali, Indonesia, 25-29 April.

BouYsSE P. (1979). - Caractères morphostructuraux et évolution géodynamique de l'arc insulaire des Petites Antilles (Campagne Arcante

1). - Bulletin du Bureau de Recherches Géologiques et Minières,

2, 185-210.

BouYsSE P. (1988). - Opening of the Grenada back-arc basin and evolution

of the Caribbean plate during the Mesozoic and early Paleogene. -

Tectonophysics, 149, 121-143

BouYsSe P. \& WeSTERCAMP D. (1988). - Effets de la subduction de rides océaniques sur l'évolution d'un arc insulaire: l'exemple des Petites Antilles. - Géologie de la France, 2/3, 2-38

BouYsSE P. \& WesterCAMP D. (1990). - Subduction of Atlantic aseismic ridges and Late Cenozoic evolution of the Lesser Antilles island arc. - Tectonophysics, 175, 349-380.

Bouysse P., Schmidt-Effing R. \& Westercamp D. (1983). - La Desirade

island (Lesser Antilles) revisited: Lower Cretaceous radiolarian cherts and arguments against an ophiolitic origin for the basal complex. - Geology, 11, 244-247.

BouYsSE P., WestercAmP D. \& AndREIEFF P. (1990). - The Lesser Antilles island arc. In: A. MASCLE, J.C. Moore et al., Eds, Proceedings of the Ocean Drilling Program, Scientific Results, 110, 29-44. Calcagno P., Bouchot V., Thinon I. \& Bourgine B. (2012). - A new 3D fault model of the Bouillante geothermal province combining onshore and offshore structural knowledge (French West Indies). - Tectonophysics, 526-529, 185-195.

CoRdey F. \& CoRnÉE J-J. (2009). - Late Jurassic radiolarians from La Desirade basement complex (Guadeloupe, Lesser Antilles arc) and tectonic implications. - Bulletin de la Société géologique de France, 180, 399-409. 
CORNÉE J.-J., LÉTICÉE J.-L., MÜNCH P., QUILLÉVÉRÉ F., LEBRUN J.-F., Moissette P., Braga J.-C., Melinte-Dobrinescu M., De Min L., OUdET J. \& RANDRIANASOlo A. (2012). - Sedimentology, palaeoenvironments and biostratigraphy of the Pliocene-Pleistocene carbonate platform of Grande-Terre (Guadeloupe, Lesser Antilles forearc). - Sedimentology, 59, 1426-1451.

Corsini M., LaRdeaux J.-M., Verati C., Voitus E. \& Balagne M. (2011). Discovery of Lower Cretaceous synmetamorphic thrust tectonics in French Lesser Antilles (La Désirade island, Guadeloupe): Implications for Caribbean geodynamics. - Tectonics, 30,

TC4005

De Min L. (2014). - Sismo-stratigraphie multi-échelles d'un bassin d'avantarc: Le bassin de Marie-Galante, Petites Antilles. - Thèse

Doctorat, Univ. Antilles-Guyane, $355 \mathrm{p}$.

De Min L., Lebrun J.-F., Cornée J.-J., Munch P., Leticee J.-L., Quillevere

F., Melinte-Dobrinescu M., Randrianasolo A., Marcaillou B.

\& ZAMI F. (2015). - Tectonic and sedimentary architecture of the

Karukéra spur: A record of the Lesser Antilles fore-arc deformation since the Neogene. - Marine Geology, 363, 15-37.

Demets C., Jansma P.E., Mattioli G.S., Dixon T.H., Farina F., Bilham

R., Calais E. \& Mann P. (2000). - GPS geodetic constraints on Caribbean-North America plate motion. - Geophysical Research Letters, 27, 437-440.

FeullLet N., MANighetTi I. \& TAPPonNier P. (2001). - Active arc - transverse normal faulting in Guadeloupe (French lesser antilles). Comptes Rendus de l'Académie des Sciences, Paris, Sci. Ser. IIa, 333, 583-590.

Feuillet N., Manighetti I., Tapponnier P. \& Jacques E. (2002). - Arc parallel extension and localization of volcanic complexes in Guadeloupe, Lesser Antilles. - Journal of Geophysical Research,

107, B12, 2331.

Feuillet N., Leclerc F., Tapponnier P., Beauducel F., Boudon G., Le Friant A., Deplus C., Lebrun J.-F., Nercessian A., Saurel

J.-M. \& CLEMENT V. (2010). - Active faulting induced by slip partitioning in Montserrat and link with volcanic activity: New insights from the 2009 GWADASEIS marine cruise data. - Geophysical Research Letters, 37, Issue 19, L00E15.

Feuillet N., Beauducel F., Jacques E., TApponnier P., Delouis B., Bazin

S., VALLEE M. \& King G.C.P. (2011). - The Mw=6.3, November

21, 2004, Les Saintes earthquake (Guadeloupe): Tectonic setting, slip model and static stress changes. - Journal of Geophysical Research, 116, B1030.

JACOUES D. \& MAURY R.C. (1988). - Carte géologique au 1/20 000e, département de la Guadeloupe, Les Saintes. - BRGM, Service Géologique National, Orléans.

JaCques D., Maury R.C. \& Bellon H. (1984). - Géologie et géochronologie

des îles des Saintes, Guadeloupe. - Comptes Rendus de

l'Académie des Sciences, Paris, serie II, 299, 11, 721-726.

Laigle M., Becel A., De Voogd B., Sachpazi M., Bayracki G., Lebrun

J.-F. \& Evain M. (2013). - Along-arc segmentation and interaction of subducting ridges with the Lesser Antilles subduction forearc crust revealed by MCS imaging. - Tectonophysics, 603,

32-54.

LaRdeauX J.-M., Munch P., Corsini M., CorneE J.-J., Verati C., Leticee J.-L., Lebrun J.-F., FieTZKe J., MaZABRAud Y. \& RANDRianasolo A. (2013). - La Désirade island (Guadeloupe, French West Indies): a key target for deciphering the role of reactivated tectonic structures in Lesser Antilles arc building. In: J.-F. LEBRuN and B. Marcaillou, Eds., Caribbean Geosciences. - Bulletin de la Société géologique de France, Special Issue, 184, 21-34. Leclerc F., Feulletet N., Cabioch G., Deplus C., Lebrun J.-F., BATHYSAINTES cruise scientific party, BEAUDUCEL F., BOUDON G., Lefriant A., De Min L. \& MelezAn D. (2014). - The Holocene drowned reef of Les Saintes plateau as witness of a longterm tectonic subsidence along the Lesser Antilles volcanic arc in Guadeloupe. - Marine Geology, 355, 115-135.

Lopez A.M., Stein S., Dixon T., Sella G., Calais E., Jansma P., Weber J. \& LAFEMINA P. (2006). - Is there a northern Lesser Antilles forearc block? - Geophysical Research Letters, 33, L07313.

Mathieu L., Van Wyk De VRies B., Pilato M. \& Troll V.R. (2011). The interaction between volcanoes and strike-slip, transtensional and transpressional fault zones: analogue models and natural examples. - Journal of Structural Geology, 33, 898-906.

Mathieu L., Van Wyk De VRies B., Mannessiez N., Mazzoni N., Savry 
C. \& Troll V.R. (2013). - The structure and morphology of the Basse Terre island, Lesser Antilles volcanic arc. - Bulletin of Volcanology, 75, 700.

Mattinson J.M., Pessagno E.A. JR., Montgomery H. \& Hopson C.A. (2008). - Late Jurassic age of oceanic basement at La Désirade island, Lesser Antilles arc. In: J. WRIGHT and J. SHERVAIS, Eds, Ophiolites, arcs, and batholiths: a tribute to Cliff Hopson. Geological Society of America Special Paper, 438, 175-190. Mauffret A., Westbrook G.K., Truchan M. \& Ladd J. (1984). - The relief of the oceanic basement and the structure of the front of the accretionary complex in the region of sites 541, 542, and 543. In: B. BiJu-Duval, J.C. Moore et al., Init. Repts. DSDP, 78A: Washington, D.C. (U.S. Govt. Printing Office), 49-62.

Münch P., Lebrun J.-F., CorneE J.-J., Thinon I., Guennoc P., Marcaillou B., Begot J., Bertrand G., Bes De Berc S., Biscarrat K., Claud C., De Min L., Fournier F., Gailler L.-S., Graindorge D., Leticee J.-L., Marie L., Mazabraud Y., Melinte-Dobrinescu M., Moissette P., Quillevere F., Verati C. \& Randrianasolo A. (2013). - Pliocene to Pleistocene carbonate systems of the Guadeloupe archipelago, French Lesser Antilles: a land and sea study (the KaShallow project). In: J.-F. LEBRUN and B. Marcalllou, Eds., Caribbean Geosciences. - Bulletin de la Société géologique de France, Special Issue, 184, 1, 99-110. Münch P., CorneE J.-J., Lebrun J.-F., Quillevere F., Verati C., Melinte-Dobrinescu M., Demory F., Smith B., Jourdan F., LaRdeaux J.-M., De Min L., Leticee J.-L. \& RandRianasolo A. (2014). - Pliocene to Pleistocene vertical movements in the forearc of the Lesser Antilles subduction: insights from chronostratigraphy of shallow-water carbonate platforms (Guadeloupe archipelago). - Journal of the Geological Society, London, 171, 329-341.

Nicoldin F., Gibert D., Beauducel F., Boudon G. \& Komorowski J.-C. (2006). - Electrical tomography of La Soufrière of Guadeloupe volcano: Field experiments, 1D inversion and qualitative interpretation. - Earth and Planetary Science Letters, 244, 709-724. Olivet J.-L., Bonnin J., Beuzart P. \& Auzende J.-M. (1984). - Cinématique de l'Atlantique Nord et Central. - Rapport Science et Technique IFREMER, 54, 106 p. + 42 pl Patrier P., Bruzac S., Pays R., Beaufort D., Bouchot V. \& Verati C. (2013). - Occurrence of K-feldspar-bearing hydrothermal breccias in the Bouillante geothermal field (Basse Terre - Guadeloupe). In: J.-F. LeBrun and B. Marcaillou, Eds., Caribbean Geosciences. - Bulletin de la Société géologique de France, Special Issue, 184, 119-128.

RoWLAND J.V. \& SiBSON R.H. (2004). - Structural controls on hydrothermal flow in a segmented rift system, Taupo volcanic zone, New Zealand. - Geofluids, 4, 4, 259-283.

Samper A., Quidelleur X., LahitTe P. \& Mollex D. (2007). - Timing of effusive volcanism and collapse events within an oceanic arc island: Basse-Terre, Guadeloupe archipelago (Lesser Antilles arc). Earth and Planetary Science Letters, 258, 175-191.

SANDWELL D.T. \& SMITH W.H.F. (2009). - Global marine gravity from retracked Geosat and ERS-1 altimetry: ridge segmentation versus spreading rate. - Journal of Geophysical Research, 114 (B01411), $1-18$

Stein S., Engeln J.-F., Wiens D.A., Speed R.C. \& Fujita K. (1982). -Subduction seismicity and tectonics in the Lesser Antilles arc. Journal of Geophysical Research, 87, 8642-8664.

Thinon I., Guennoc P., Bitri A. \& TrufFert C. (2010) - Study of the Bouillante Bay (West Basse-Terre island shelf): contribution of geophysical surveys to the understanding of the structural context of Guadeloupe (French West Indies - Lesser Antilles) Bulletin de la Société Géologique de France, 181, 1, 51-65. Verati C., Patrier-Mas P., Lardeaux J.-M. \& Bouchot V. (2014). - Timing of geothermal activity in an active island-arc volcanic setting: preliminary 40Ar/39Ar data from Bouillante geothermal field (Guadeloupe, French West Indies). In: F. JouRDAN, D.F. MARK and C. Verati, Eds, Advances in 40Ar/39Ar dating. Archaeology to Planetary Sciences. - Geological Society, London, Special Publications, 378, 285-295

WESTERCAMP D. (1979). - Diversity, structural control and origin of recent volcanism in the Lesser Antilles island arc. - Bulletin du Bureau de Recherches Géologiques et Minières, Sect. IV, 3-4, 211-226. Westbrook G.K., Mascle A. \& Biju-Duval B. (1984). - Geophysics and 
the structure of the Lesser Antilles forearc. In: J.C. MooRE and B. BIJu-Duval, Eds., Init. Repts. DSDP, 78A: Washington, D. C. (U. S. Govt. Printing Office), 23-38.

Zami F., Quidelleur X., Ricci J., Lebrun J.-F. \& SAmper A. (2014). - Initial sub-aerial volcanic activity along the central Lesser Antilles inner arc: New K-Ar ages from Les Saintes volcanoes. - Journal of Volcanology and Geothermal Research, 287, 12-21.

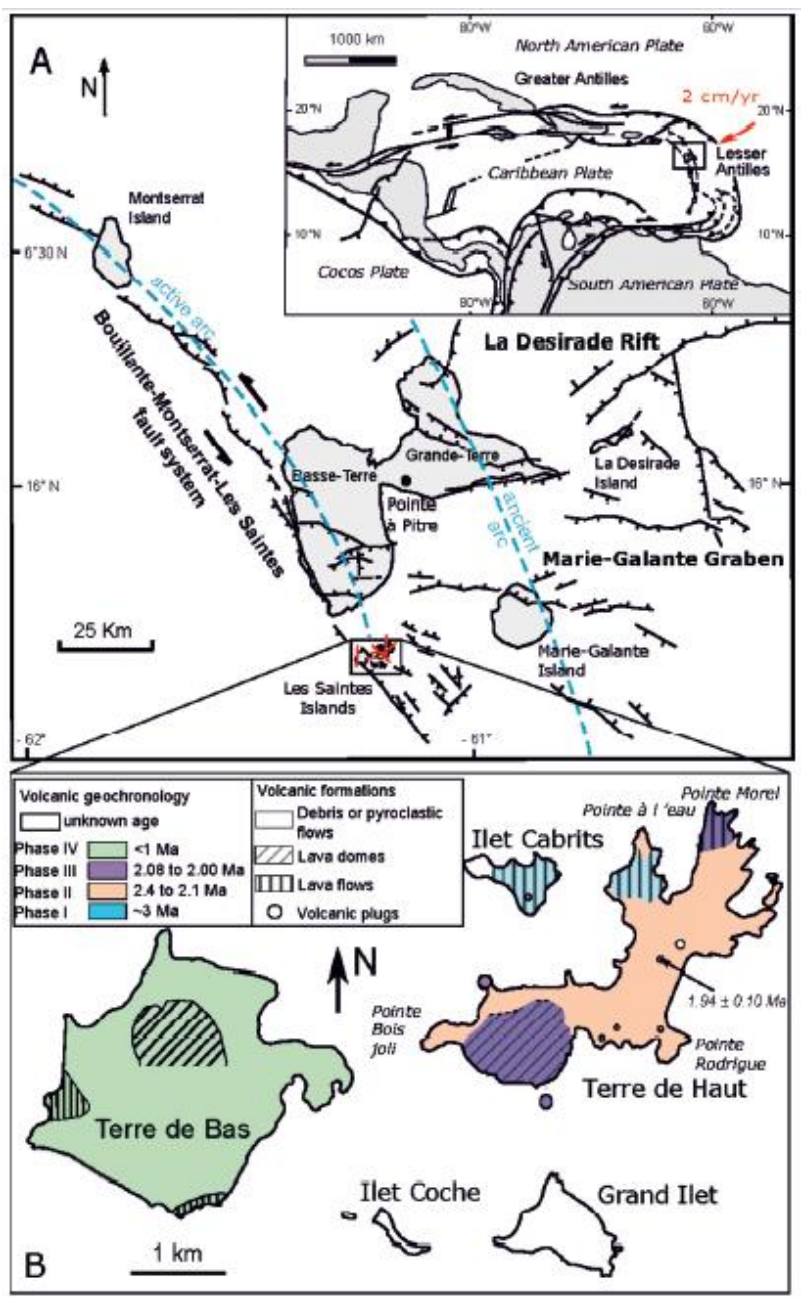

FIG. 1. - A) Geodynamic setting of the Lesser Antilles arc [after Feuillet et al., 2002; De Min et al., 2015]. The red lines represent the major faults observed on Les Saintes islands. B) Simplified geological map of Les Saintes archipelago [modified after Jacques et al., 1984; Jacques and Maury, 1988]. The volcanic ages were defined according to the new radiometric $\mathrm{K}$-Ar ages from Zami et al., 2014 (see text for explanation). The indicated age of $1.94 \pm 0.10 \mathrm{Ma}$ on an unaltered volcanic plug is from Jacques et al., 1984. 


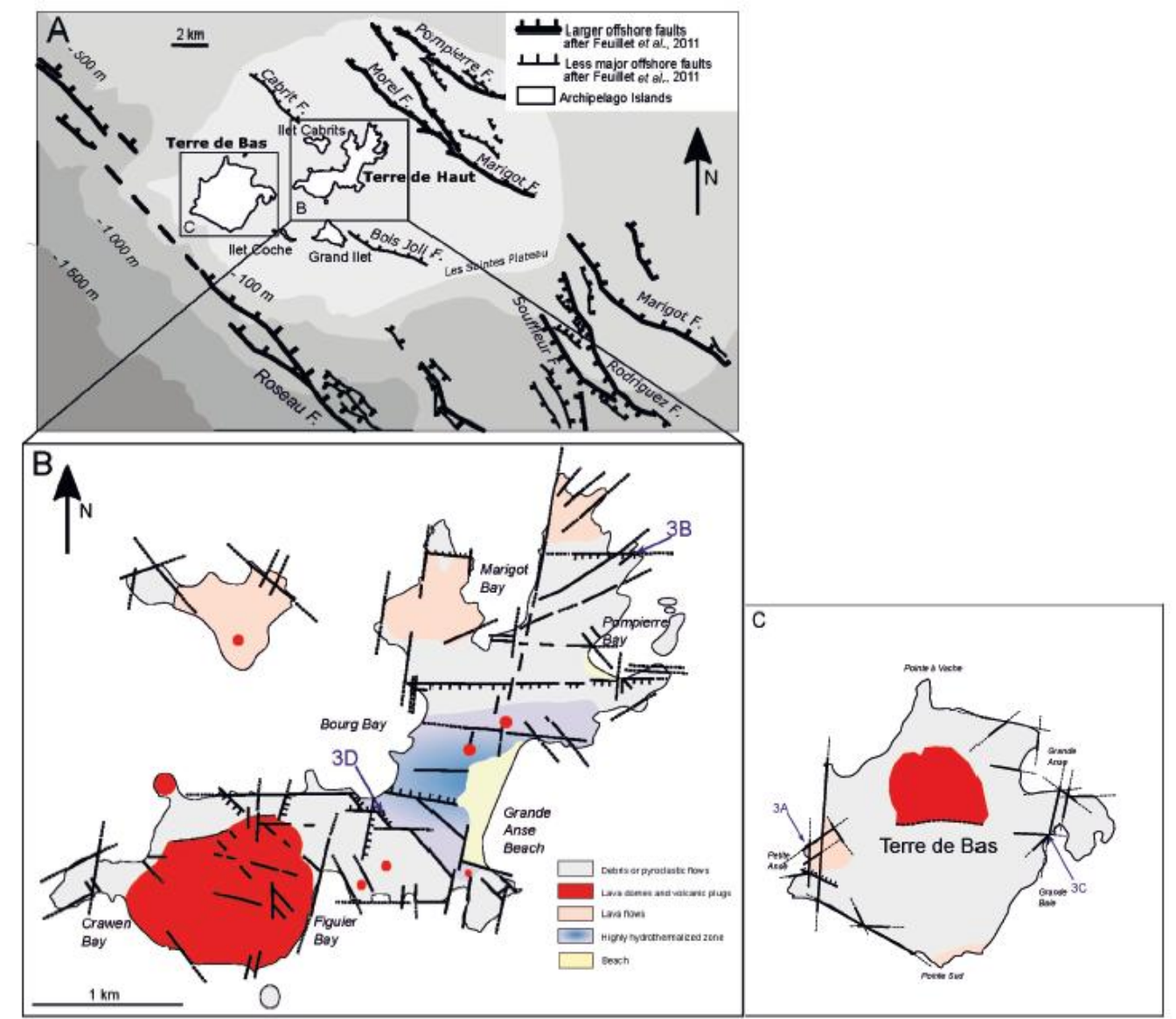

FIG. 2. - A) Map of offshore active faults surrounding Les Saintes islands [after Feuillet et al., 2011; Leclerc et al., 2014]. B) Tectonic sketch map

of Terre-de-Haut island where the main faults observed are reported. C) Tectonic sketch map of Terre-de-Bas island. Locations of the photographs from the

figure 3 are reported (3A to 3D).

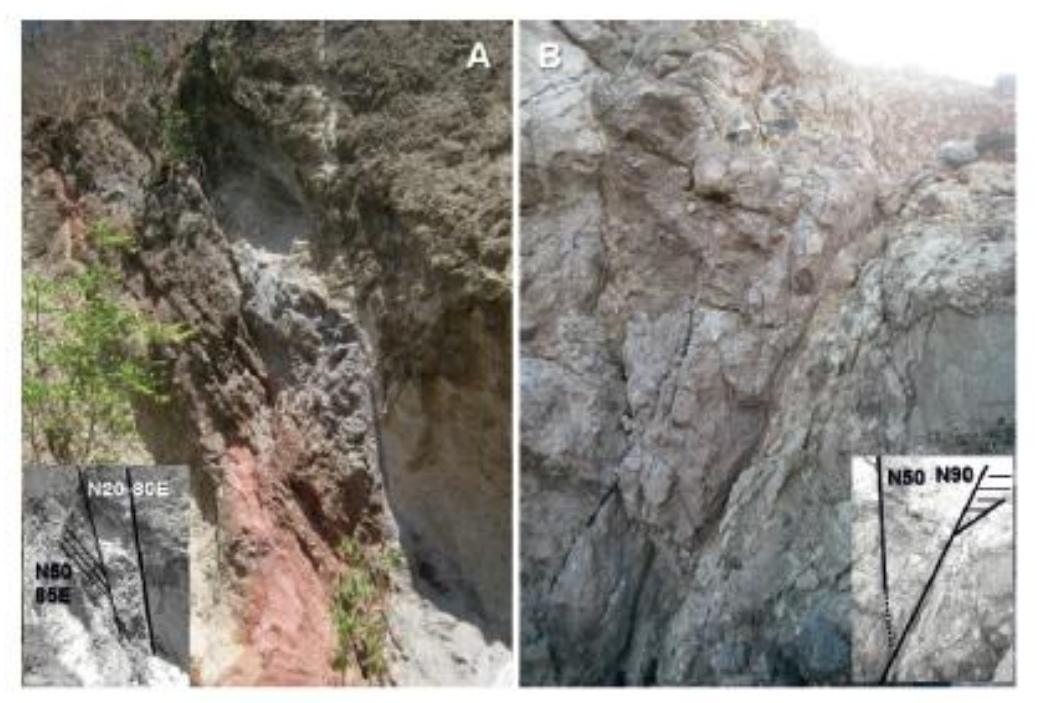




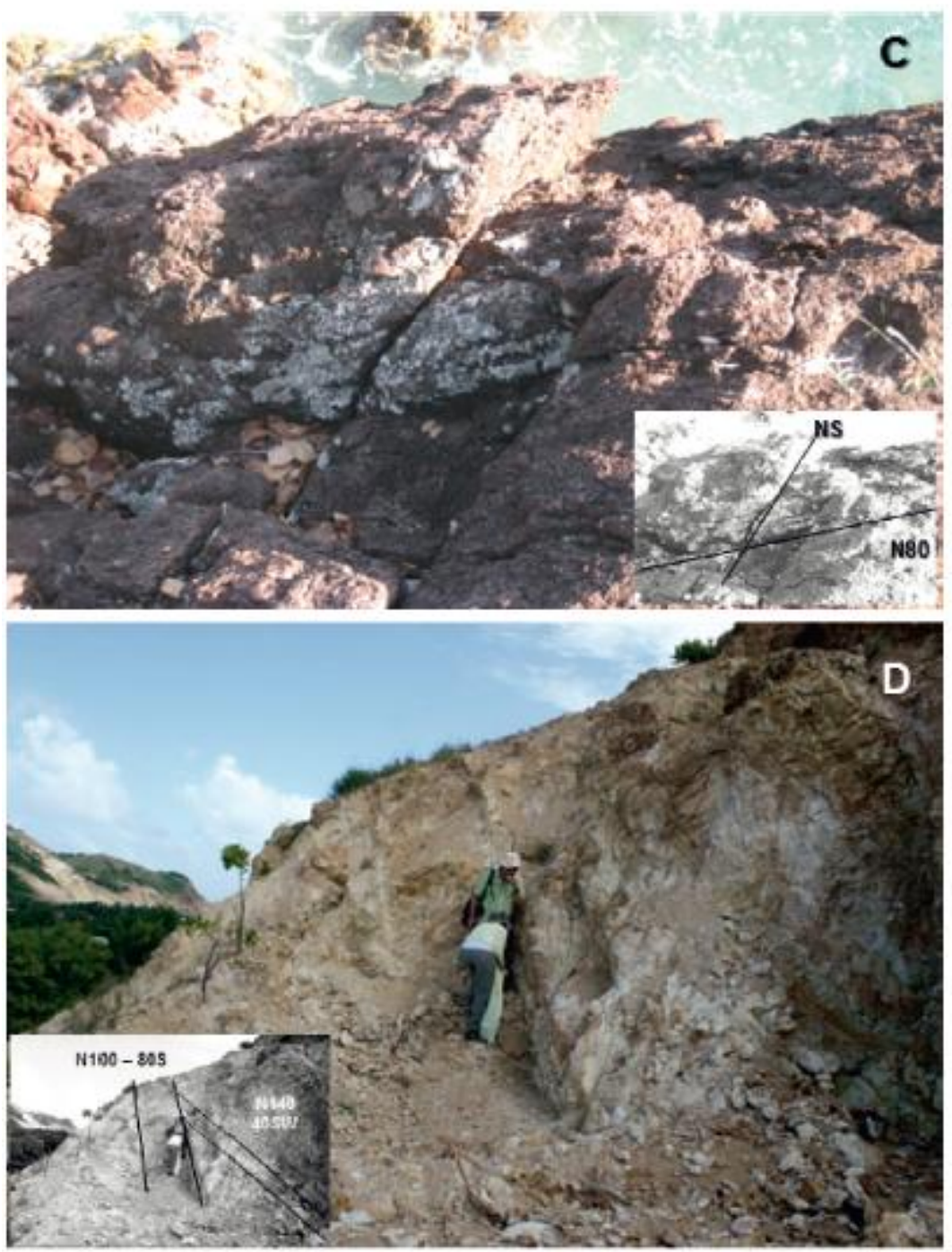

FIG. 3. - Field photographs of significant faults in Les Saintes islands (see the figure 2 for their locations). A) A N020 strike-slip normal fault crosscutting oldest N050 faults in the Terre de Bas island. B) A N090 fault in pyroclastic flows, crosscutting the N050 fault system in the Terre-de-Haut island. C) Significant brittle N-S fault crosscutting the N080 fault system, Terre-de-Bas island. D) Significant N100 faults within highly hydrothermalized area, crosscutting N140 trending faults at aerodrome area, Terre-de-Haut island. 


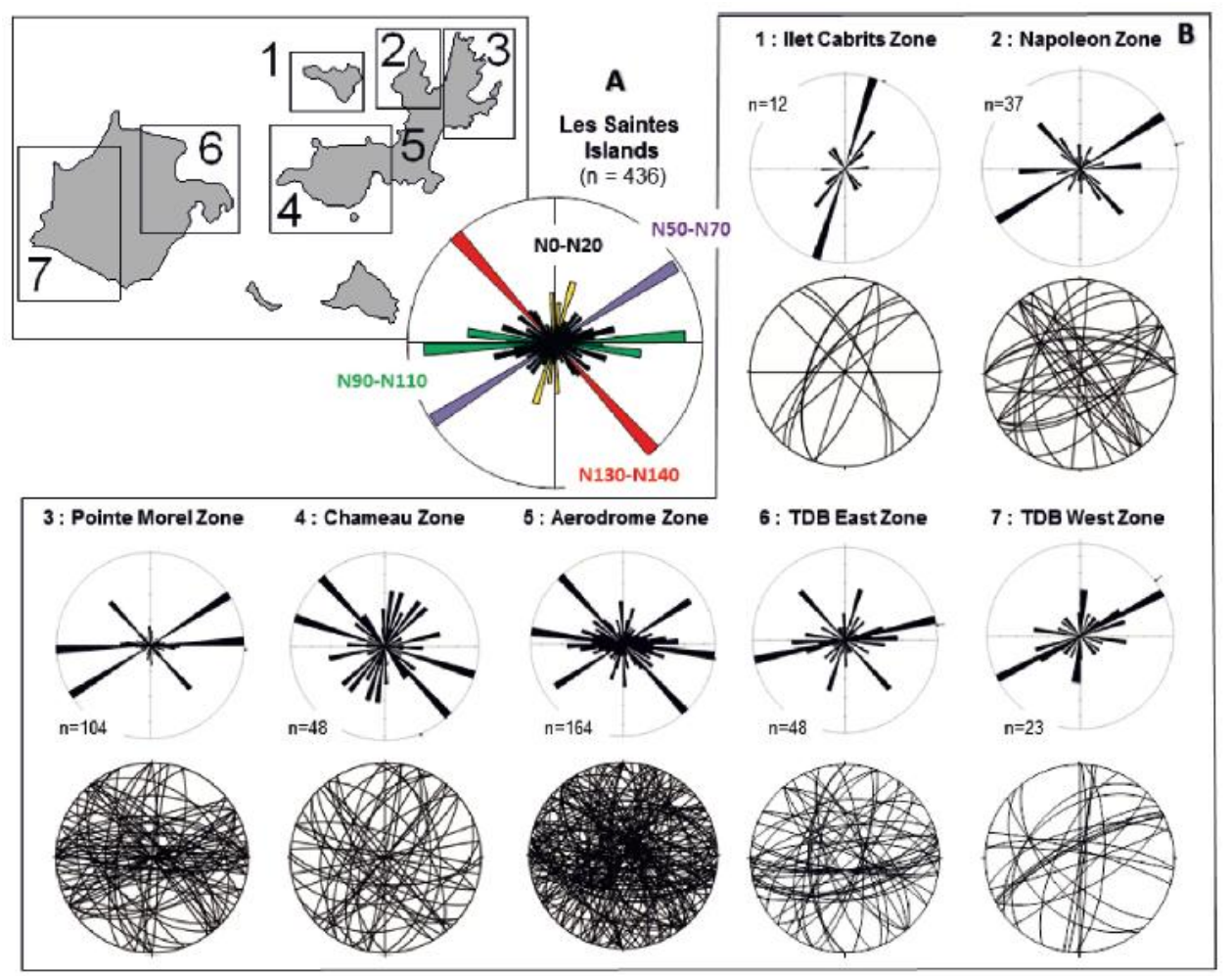

FIG. 4. - A) Rose diagram for all the observed faults in Les Saintes islands $(n=436)$, B) Detailed rose diagrams and stereograms of different areas from the archipelago.

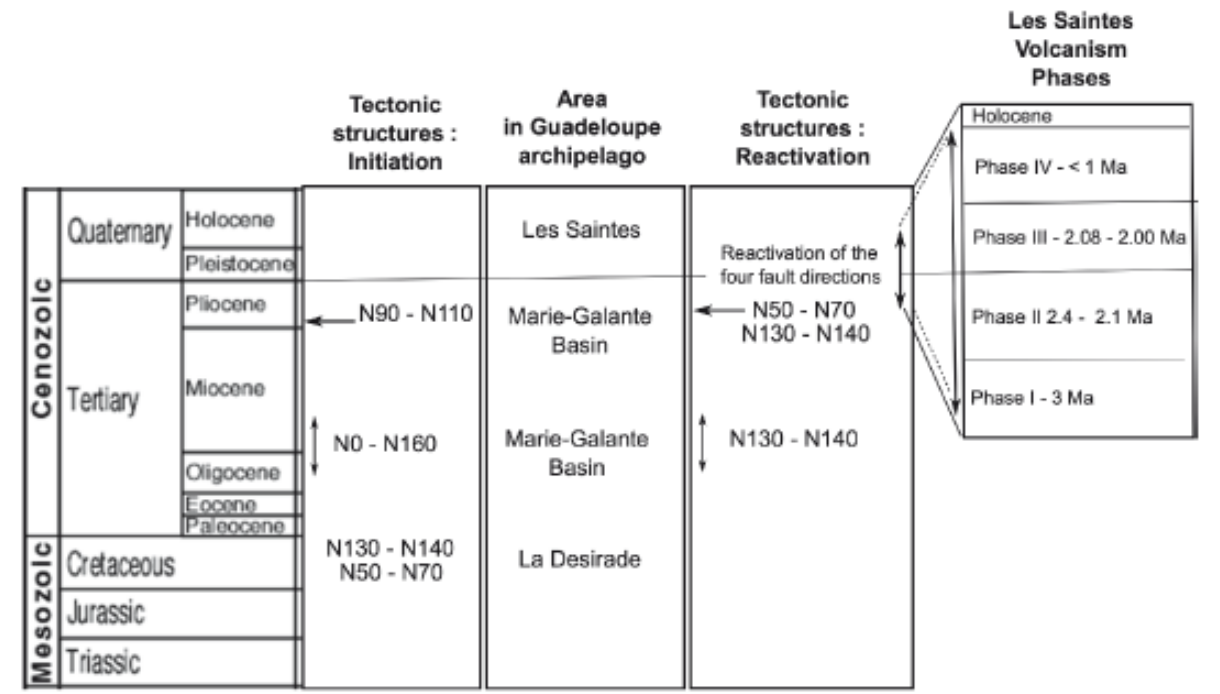

FIG. 5. - Synthetic table showing the timing of the tectonic structure development at the scale of the archipelago including Les Saintes islands. 